\title{
From Action Art to Artivism on Instagram: Relocation and instantaneity for a new geography of protest
}

\begin{abstract}
This article addresses how the concept of 'Action Art', which came mainly from the anti-cultural movements of May 1968 in Europe, has been transformed into the term Artivism. The main hypothesis is that it is a succession of committed and protest art, transformed by two fundamental elements: the emergence of social networks and the exposure of a very young audience to artistic creation through this network. This type of creative action has acquired an urban character that is strongly linked to civil protest movements. In the second part, this article discusses how both terms circulate as Instagram hashtags in this delocalized world of networks. The terms are used to show that, beyond transcending national territories, new, significant geographies are continually being reconstructed.
\end{abstract}

\section{INTRODUCTION}

The objectives of this article are, first, to reflect on the origins of the so-called 'Action Art' and its transformation into Artivism, due to the use of social networks that create a delocalized panorama of political art that is engaged in

\section{KEYWORDS}

Artivism

Action Art social networks Instagram artists and the Internet instantaneity social protests art activism 
the present. Secondly, to investigate the circulation of the term on Instagram, a social network that uses mostly images, using a quantitative study of hashtags directly related to Artivism and its forms.

The central hypothesis is that originally Action Art was linked to the space-time in which the artistic manifestation took place. These exhibitions have been transformed and have become what today is called Artivism. This evolution is a product of the socio-political circumstances that have existed from the end of the twentieth century to the present. However, above all it has been due to the emergence of social networks that have provided unlimited communication between creators and recipients, while also allowing each recipient to become an information-transmitting agent. In short, this new phase of Action Art is called Artivism. It involves not only the dissemination of the art of political action through the Internet, but the transformation of twentieth-century protest art.

\section{STATE OF THE QUESTION}

Some theorists have traced the origin of Action Art to the first avant-garde movements, especially the Dadaist and Futurist movements, but it was not until the second half of the twentieth century and in the specific context of the sixties and seventies, when it acquired some clear, differentiating features, with a theme related to the desire to achieve a social and political transformation, and the need to create an alternative culture in a quickly changing social context.

The truth is that Action Art can be defined not so much by its formal characteristics, as by the idea that it is an 'event', something that happens once in time and disappears. The artistic act is an experience rather than the production of an object to be contemplated. It tries to approach the effects that ancient rituals could have in which people cathartically participated, in the sense that it requires the participation of the body, both that of the artists and the spectators. It must be said that the irruption of women's artistic creations has been a fundamental element in this adaptation, since the body and identity as an element of artistic development have been the central themes for women (Pérez and Corey 2015). From the 1970s to the present, many artists have worked on producing meanings of identity, but also of belonging, especially through a negotiation of the authenticity of personal identity, using the body in Body Art, which then artists have distributed massively through social networks (Riley and Cahill 2005).

The term 'Action Art' was created by the American artist Allan Kaprow. Under that definition, artists searched for new artistic media, investigated new modes of expression far from the canons imposed by the pictorial and sculptural tradition, and tore down the boundaries between the Fine Arts and Applied Arts. The May 1968 anti-cultural movement provoked socio-political transformations, which also affected the plastic arts. One of the most important characteristics in this process has been the relationship of art with everyday experience, with the elimination of the dichotomy between art and life. Commitment to the new Action Art meant using collages, performances, photo-action or video installations, creative strategies that initiated a new relationship between art, the public, and ultimately social life and ways of organizing protests.

For Academia, it continues to be a difficult task to define the origin of artistic manifestations that include performances and the body in action, and 
as time goes by this is becoming impossible (Howell 1999; Goldberg 2011). For this reason, it is perhaps better to avoid the formal or creative characteristics of the works or artists, and reflect on the theoretical categories that Fredric Jameson (1992) developed to interpret and systematize the characteristics of so-called 'postmodern art', such as the art developed especially after the great ideological crisis represented by the Second World War. For Jameson (1992), contemporary art is characterized by its fragmentary character and its development in an environment of technological complexity. Its major characteristic is the end of the author as individual figure and creative genius. Postmodern creators have a collective vocation because they consider themselves part of a social and historical framework and not individual geniuses.

This collective and anonymous spirit can be found in different collectives such as Wu Ming; they generate literary works anonymously and collectively, and the Guerrilla Girls, who conceal their personal identities, while criticizing the lack of presence and representation of women in art. Another characteristic feature is that the works seek impact and instantaneity, in the face of the transcendence of modern artistic works. None of these works pays homage to the artistic tradition, but they do use previous texts with a pastiche or collage effect. The use of non-museum spaces and perishable materials has to do with the resistance of artists to be integrated into the official institutions of the art business. Finally, on the formal level, postmodern works play with anti-form, with the anarchy of formal elements that are exposed without a hierarchy, with hypertext, irony and indeterminacy. It is very common for works and actions to convey a sense of chaos and heterogeneity, and often a taste for the degraded and kitsch.

From the perspective provided by Jameson (1992), Action Art is actually an art that opposes what art represented in the modern period and we can only understand and interpret it through that contrast. While modern art was a transcendent art that exalted the figure of the author-genius-creator and it had no use in practical life (it was'art for art's sake'), postmodern art subverts all these categories allowing the irruption of the ephemeral, the unimportant, the political and the collective. These theoretical characteristics of how postmodern art is configured make it easier to also understand the manifestations of Action Art and Artivism. It is not so much a formal question of the works that are produced as the intention of the people who create them, and the consumption, reproduction and interpretation of the people who receive them and put them into circulation on social networks.

In this complex context, the extension of new technologies has brought about the end of the monopoly of specialized art registries. Artistic images are now everywhere. They are no longer the heritage of museums or specialized magazines. Users create images and situations that they can disseminate without limit. Even many of the performances that were made during the 1960s and 70s, which were created with the idea of not transcending or enduring, are now available to the public, in all homes, on platforms as widely used and accessible as YouTube.

Current Artivism consists in the redefinition of Action Art, which has been transformed by the use of social networks and due to its highly urban, critical and combative character. Artivism is a word formed by 'art' and 'activism', which began to develop with the anti-globalization movements that grew in opposition to multinationals and international organizations such as the International Monetary Fund and the World Bank, considered the culprits of the growing inequality in the world (Weibel 2015). These movements gained 
visibility in 1999, when a large number of people demonstrated in Seattle during a meeting of the World Trade Organization. From that moment on, a large number of networks reached the general public through the Internet. They were decentralized and functioned horizontally and their objective was to turn civil society into an active agent of political change. At that time, the first communications network was created with the goal of providing free, alternative news to media organizations: Independent Media Center (Indymedia or $\mathrm{IMC})$, which has been the basis of alternative platforms for social activism.

Artivism emerged in this context of a civil society that was acutely aware of its ability to intervene in political agendas (Poch and Poch 2018a, 2018b). It is a critical art, a continuator of political art, which uses social networks as an instrument of basic communication. One of its main features is that it develops in urban environments and posits the appropriation of public space as a strategy to fight multinationals, consumption and unequal globalization, which is leaving a large number of people worldwide without any rights or material well-being. Artivism has become even more meaningful, if possible, with the explosion of the housing bubble and the western financial crisis beginning in 2008. In Spain, there were mobilizations around the so-called 15M, a citizen movement that arose from the demonstrations of 15 May 2011. In these protests, different groups and organizations claimed that politics was actually managed by citizens, in an attempt to overcome the traditional bipartisanship (Partido Popular - Partido Socialista) that has dominated political life in Spain since democracy was restored in 1978.

Artivism continues to be defined at present with rather general and unspecific terms, such as a'global language' (Aladro et al. 2018: 9). Current Artivism is indebted to the critical urbanism developed from the urban walks theorized and formalized by the urbanist and Canadian activist Jane Jacobs (1916-2006) who, in her classic work The Death and Life of Great American Cities (1961), created such fundamental concepts as 'social capital' and 'spontaneous selforganization of urbanism' and the idea that the urban space is a public space that must be reclaimed to promote coexistence and the attainment of a good quality life for its citizens.

The topics discussed in the forums that define themselves as artivists have to do with social aspects such as climate change (Treré and Mattoni 2016), criticism of uncontrolled tourism, respect for animals, political corruption, human rights, citizen security, borders, refugees, feminism, in many cases with an educational function (Bishop and Corkery 2017; Goris and Hollander 2017). Young people, in particular, use social networks mainly for their protests (Postill 2014) and have generated a highly specialized rhetorical language in this type of demonstration that they already perceive as intertextual and thematically transversal (Huntington 2016), in addition to being highly qualified in the use of digital tools (Simoens and Campos 2016). In recent years, their participation and political involvement in civil and citizen protests has continued to increase. This phenomenon, without a doubt, has to do with the fact that the youngest segment of the population is the most attentive to the information that is created and distributed on social networks (Milner 2013; Treré and Mattoni 2016).

A paradox that occurs in the highly dislocated and disembodied context of social networks is that the use of the artist's body has not disappeared as an element that is displayed to others as an element of battle politics. Jack Bratich (2014), for example, analysed how many of the people involved in the Occupy Wall Street protest used their body as audio-visual devices to narrate the process of subjectivization. 
The number of social network users worldwide also means it is essential to know and value their relationship with Artivism and Action Art. In 2018, it is estimated that the social networks with the most active users in the world are, in decreasing order: Facebook (2.13 billion users), YouTube (1.5 billion), Instagram (800 million), LinkedIn (530 million), Google+ (395 million), Snapchat (356 million) and Twitter (330 million). The internal and national social networks of countries like China and India are not considered because although they feature millions of users, they do not operate in the five continents.

In Spain, Instagram is the second most popular social network, after Facebook and before Twitter; and the one that has grown the most since its creation (Smith 2018). It is estimated that it has more than thirteen million active Spanish users in 2018 (De Lis 2017). In 2017, it grew 35.41\% compared to the previous year; while Twitter only grew $8.8 \%$ and the number of Facebook users fell by $4.16 \%$. In addition, it is the favourite network of millennials (Dalziell and Kim 2015; Lane and Dal Cin 2017). Some 65\% of its users are under 39 years old, $54 \%$ are women, and $46 \%$ are men (The Social Media Family 2018). In July 2017, Instagram published official data for 700 million users around the world. The previous data were from December 2016, when there were 600 million users. This growth is astronomical and unprecedented. In fact, the number of consumers may be even greater since the company only counts those who uploaded a photo or a comment in the 30 days prior to the official report.

As the bibliography on Artivism and social networks is so varied and general, other relevant works from nearby fields have also helped as a scientific base. Reference is made to the work on the new reporting functions of social networks (Korpijaakko 2015; Alvídrez and Franco 2016; Manovich 2016; Russmann and Svensson 2016; Torrego and Gutiérrez-Martín 2016; Jivkova et al. 2017; Saura et al. 2017), digital Activism and Artivism (Lim 2012; Tufekci and Wilson 2012; Zhang 2013; Herrero-Diaz and Ramos-Serrano 2018), social networks as a citizen participation tool (Míguez-González and Huertas 2015; Dias-Fonseca and Potter 2016; Caldeira and De Ridder 2017; Sendra and Farré 2017; Senabre et al. 2018), cybercitizenship (Cmeciu and Coman 2016; DíezGutiérrez and Díaz-Nafría 2018) and social empowerment (Camilli-Trujillo and Römer-Pieretti 2017; Castihlo and Romancini 2017). Taking into account that Artivism reaches all audiences, of all ages, the effects of new technologies on interpersonal communication are also considered (Andújar-Vaca and CruzMartínez 2017), as well as research on social networks and new technologies in the classroom, thinking of media literacy as a possible model to imitate in artistic literacy (Tuzel and Hobbs 2017).

\section{MATERIAL AND METHODS}

This article contains two consecutive and diachronic research phases: (1) a longitudinal, analytical-synthetic bibliographic exploration, which reflects on the origins and transformation of so-called 'Action Art' into Artivism in academic texts, due to the use of social networks that depict a delocalized panorama of political art committed to the present. The selection criteria of the academic texts included the impact of the publications, the number of citations, the impact of the journals or publishing houses where they were published for their inclusion in prestigious databases (Journal Citation Reports, Scimago Journal \& Country Rank and Scopus), and their rigour in the publication 
process; (2) a correlational inquiry, which measures the current reciprocity between Action Art and Artivism in social networks, based on images and their hashtags.

The first step involved two years of collaboration between Spain, France, Hungary and the United Kingdom, and the production of a thesaurus comprising high impact international academic works, many shared in the introduction and state of the question section of this article. This thesaurus is shared by the entire project team in the cloud, and will be published on the project website (http://artivism.online/) to make it available to the entire scientific community, with the aim of strengthening the scientific basis of Artivism.

The second step, empirical and quantitative, is cross-descriptive. It collects some of the most successful hashtags published in the first half of 2018 using the Keyhole software tool, Keyhole, Inc., 2001, which was acquired by Google three years later. Currently, it has capital from Sony, Nvidia and In-Q-Tel, the technological entity of the CIA (Central Intelligence Agency or Central American Intelligence Agency). Its tools are part of the Google Earth and Google Maps applications, among many others.

Twitter and Instagram have multiplied the possibilities of delocalizing political and committed art. Founded in 2006 and 2010, respectively, they eliminated the need for a physical encounter between the audience and the artists or their work. Artistic diffusion became global and ubiquitous. Due to the number of users around the world and its exponential growth, Instagram serves to fulfil the second objective of this study: to investigate how the term Artivism circulates through the social network, which is mainly based on sharing images. To this end, a quantitative analysis of the hashtags directly related to Artivism and Action Art will be conducted.

Instagram is a free, simple and very visual social network that enables photos and videos (of less than a minute) to be uploaded and commented on, or Instagram Stories, mini videos of up to ten seconds that are deleted automatically after 24 hours. Although originally, it was created for iPhone, iPad and iPod Touch, two years later, in April 2012, it was extended to the Android operating system. From the outset, it was established exclusively for mobile phones and currently it is not possible to upload photos from the web version. Nevertheless, it allows the profile picture to be selected and modified from a desktop computer.

The application was created and developed by Kevin Systrom and Mike Krieger (Chen 2017). Systrom was born in 1983, in Holliston, Massachusetts, United States, and graduated in Engineering, in 2006, from Stanford University. Krieger was born in 1986, in São Paulo, Brazil, and coincided with Systrom at university. He graduated in 2008 and worked at Symbolic Systems, an original Stanford programme, which combines Computer Engineering, Linguistics, Philosophy and Psychology. Together they launched their product on 6 October 2010, in the Apple App Store. Its first logo honoured the Kodak Instamatic the Polaroid cameras and only allowed photographs to be shared in a square format. However, the 2017 update allowed photographs to be uploaded in different formats. In addition, the filters, which are also free, give an almost professional and personalized finish to all the images (BorgesRey 2015; Choi and Lewallen 2017; Poulsen 2018).

In January 2011, Instagram introduced another important change. In the wake of Twitter, the social network encouraged its users to describe their photos with hashtags or labels. One year later, in April 2012, Facebook 
acquired Instagram for one billion dollars (Cummings 2016; Visa et al. 2018). Since May 2013, the application allows users to post on both social networks.

Considering the above, the following searches were conducted:

- The five hashtags with the greatest international diffusion related to Artivism and Action Art, published in Instagram, in English

- The number of original or primary publications, in which these hashtags appear

- The number of users who created those original or primary publications

- Users who viewed that post

- The impressions generated as a result of the original publication: mentions, retweets, and comments

- The five Instagram users that generated the most impressions

- The countries of origin of the publications and their impressions generated

- The electronic device or computer system used.

\section{ANALYSIS AND RESULTS}

The results show some of the most influential hashtags related to Artivism and published in the first semester of 2018, according to the Keyhole software tool. The concepts have been ordered from the general to the particular, from artivism to performance. Five hashtags were chosen, with the first two representing the phenomena under study, and the next three the main forms or manifestations of Artivism. We have chosen these last three hashtags because they have the greatest impact, they are the most frequently cited in
6. Acronym of Internet Protocol Television.

\begin{tabular}{|c|c|c|c|c|c|}
\hline Hashtag & Publications & $\begin{array}{l}\text { Users } \\
\text { who } \\
\text { used the } \\
\text { hashtag }\end{array}$ & $\begin{array}{l}\text { Users } \\
\text { who } \\
\text { viewed } \\
\text { the post }\end{array}$ & $\begin{array}{l}\text { Generated } \\
\text { impressions }\end{array}$ & Five most influential users \\
\hline \#artivism & 192 & 126 & $+100,000$ & $+100,000$ & $\begin{array}{l}@ \text { nevercrew @underwater. } \\
\text { photo@pangeaseed @urban- } \\
\text { nationberlin@francescaapage }\end{array}$ \\
\hline \#actionart & 136 & 21 & 78,871 & 78,871 & $\begin{array}{l}\text { @james_emirzian_waldementer } \\
\text { @rksartworld @wolfruck } \\
\text { @klaussvandamme @actionart- } \\
\text { banners }\end{array}$ \\
\hline \#netart & 122 & 16,229 & $+100,000$ & $+100,000$ & $\begin{array}{l}\text { @amazing_cyberpunk@exit- } \\
\text { simulation @cyber.dweller @ } \\
\text { holmandhimmel @kenshiro- } \\
\text { plus_official }\end{array}$ \\
\hline \#photoaction & 73 & 31 & 183 & 732 & $\begin{array}{l}@ \text { manouil_zannis@carolgeol @ } \\
\text { surfotoscontato @beachshowo- } \\
\text { ficial @instahafez_pourch }\end{array}$ \\
\hline \#performance & 330 & 302 & $+100,000$ & $+100,000$ & $\begin{array}{l}\text { @kainaatarora } \\
\text { @ scooterscootbdg@bmw__ } \\
\text { f20_daniel @KevinMUGUET @ } \\
\text { anunnaki.signal }\end{array}$ \\
\hline
\end{tabular}

Table 1: Artivism and Action Art hashtags in Instagram with more diffusion all over the world. 
the sources consulted for the theoretical framework, and they also constitute the work analysed by teachers and students in the competitive projects workshops whose results serve to produce this study.

The tag \#artedeaccion started from 28 primary publications that, in just a few weeks, generated more than 12,178 views and 27,924 impressions. This data, even though it is the hashtag of least initial significance, shows the virality and internationalization of Action Art. The \#photoaction label did not achieve that much; after 73 publications, it only reached 183 users, who generated 732 impressions in a month. However, \#actionart, \#artivism and \#performance prove that social networks have helped Artivism and Action Art overcome spatial-temporal barriers. Starting from a few dozen publications, the photographs and videos of artists reached almost 100,000 users, or more in some cases. Likewise, it is perceived that some users repeated their appearance, if the top twenty influencers are taken into account. The same thing did not happen with regard to the top five users. They are artists, mostly, but also fans and amateur artists that make their own creations or disseminate the creations of professionals and known artists.

\begin{tabular}{|c|c|c|}
\hline Hashtag & Country of origin & Electronic device used \\
\hline \#artivism & $\begin{array}{l}\text { United States: } 53.33 \% . \\
\text { United Kingdom: } 8 \% \text {. } \\
\text { France: } 6.67 \% \text {. Holland: } 6.67 \% \text {. } \\
\text { Germany: } 5.33 \% \text {. } \\
\text { Canada: } 4 \% \text {. } \\
\text { Australia: } 2.67 \% \text {. Senegal: } 2.67 \% \text {. } \\
\text { Brazil: } 1.33 \% \text {. Slovakia: } 1.33 \% \text {. } \\
\text { Spain: } 1.33 \% \text {. Georgia: } 1.33 \% \text {. } \\
\text { Norway: } 1.33 \% \text {. Peru: } 1.33 \% \text {. } \\
\text { Portugal: } 1.33 \% \text {. Switzerland: } \\
\text { 1.33\%. }\end{array}$ & $\begin{array}{l}\text { Computer/web: } 44 \% \text {. } \\
\text { IPhone: } 24 \% . \\
\text { Mobile web: } 10 \% \text {. } \\
\text { Others: } 10 \% \text {. } \\
\text { Android: } 8 \% \text {. } \\
\text { IPad: } 4 \% \text {. }\end{array}$ \\
\hline \#actionart & $\begin{array}{l}\text { United States: } 60 \% \\
\text { Spain: } 20 \% \text {. } \\
\text { The Philippines: } 20 \% \text {. }\end{array}$ & $\begin{array}{l}\text { IPhone: } 33.3 \% \text {. } \\
\text { Graffiti_bot: } 16.7 \% \text {. } \\
\text { Mobile web: } 16.7 \% \text {. } \\
\text { Android: } 16.7 \% \text {. } \\
\text { Cheap bots, done } \\
\text { quick!: } 16.7 \% \text {. }\end{array}$ \\
\hline \#netart & United States: $100 \%$. & $\begin{array}{l}\text { IPhone: } 54 \% \text {. } \\
\text { Computer/web: } 24 \% \text {. } \\
\text { Mobile web: } 12 \% \text {. } \\
\text { Others: } 10 \% \text {. }\end{array}$ \\
\hline \#photoaction & $\begin{array}{l}\text { Canada: } 40.93 \% . \\
\text { Australia: } 15.91 \% \text {. } \\
\text { Indonesia: } 11.36 \% \text {. } \\
\text { Germany: } 9.09 \% \text {. } \\
\text { Brazil: } 6.82 \% . \\
\text { Argentina: } 2.27 \% \text {. Chile: } 2.27 \% \text {. } \\
\text { Croatia: } 2.27 \% \text {. Spain: } 2.27 \% \text {. } \\
\text { United States: } 2.27 \% \text {. Holland: } \\
\text { 2.27\%. Russia: } 2.27 \% \text {. }\end{array}$ & Computer/web: $100 \%$. \\
\hline
\end{tabular}




\begin{tabular}{|c|c|c|}
\hline \#performance & $\begin{array}{l}\text { United Kingdom: } 35.47 \% \text {. } \\
\text { United States: } 21.50 \% \text {. } \\
\text { France: } 9.26 \% \text {. } \\
\text { Germany: } 3.70 \% \text {. } \\
\text { Spain: } 3.24 \% \text {. } \\
\text { Canada: } 2.78 \% \text {. } \\
\text { Australia: } 2.31 \% \text {. } \\
\text { India: } 2.31 \% \text {. } \\
\text { Italy: } 1.85 \% \text {. } \\
\text { Croatia: } 1.39 \% \text {. The Netherlands: } \\
\text { 1.39\%. Ireland: } 1.39 \% \text {. Japan: } \\
\text { 1.39\%. Kenya: } 1.39 \% \text {. } \\
\text { Austria: 0.93\%. Bangladesh: } \\
0.93 \% \text {. Brazil: 0.93\%. } \\
\text { Switzerland: 0.93\%. Turkey: } \\
\text { 0.93\%. Colombia: 0.46\%. United } \\
\text { Arab Emirates: } 0.46 \% \text {. Slovenia: } \\
\text { 0.46\%. Indonesia: 0.46\%. Nepal: } \\
0.46 \% \text {. Nigeria: } 0.46 \% \text {. New } \\
\text { Zealand: } 0.46 \% \text {. Czech Republic: } \\
\text { 0.46\%. Romania: 0.46\%. Russia: } \\
\text { 0.46\%. South Africa: 0.46\%. } \\
\text { Sweden: 0.46\%. Uganda: 0.46\%. }\end{array}$ & $\begin{array}{l}\text { Computer/web: } 42.1 \% \\
\text { IPhone: } 17.0 \% \text {. } \\
\text { Android: } 16.2 \% \text {. } \\
\text { Ifttt: } 6.4 \% \text {. } \\
\text { Buffer: } 5.1 \% \text {. } \\
\text { Mobile web: } 3.83 \% \text {. } \\
\text { Facebook: } 2.98 \% \text {. } \\
\text { Twitter lite: } 2.55 \% \text {. } \\
\text { IPad: } 2.13 \% \text {. } \\
\text { Meet edgar: } 1.70 \% \text {. }\end{array}$ \\
\hline
\end{tabular}

Table 2: Action art hashtags in Instagram with greatest diffusion, country of origin and device used.

Keyhole, as a geolocation tool, allows many other data about hashtags to be collected. Two sections are especially relevant: publications' and users' country of origin, and the devices used to interact with these publications. The countries with the most influence are: the United States, Canada, Brazil, Argentina, Peru and Colombia (North and South America), the United Kingdom, France, Germany, Holland, Russia and Croatia, among others (Europe), Senegal and Uganda (Africa), The Philippines, India, Nepal, Bangladesh and the United Arab Emirates (Asia) and Australia and New Zealand (Oceania).

The data on the devices are disaggregated and fluctuate between one label and another. However, interesting results can be found by looking at each specific hashtag. For example, in the case of \#photoaction, all users published or interacted by computer or web page. However, the iPhone stood out in \#actionart, with 33.3\%, and in second positions with \#artivism (24\%) and \#performance (17\%). In those cases, Android occupied subsequent posts: 16.7\% in \#actionart, $8 \%$ in \#artivism and 16.2\% in \#performance.

Keyhole also points to the iPad and varied applications, such as Cheap bots, done quick!, Ifttt, Buffer, Meet edgar and Twitter lite. It is striking that Facebook only appears in \#performance, with $2.98 \%$ of devices. However, this figure is understandable considering that this company acquired Instagram in 2012 and users who publish photos in the second social network can automatically publish them on Facebook. This small percentage is thus explained by residual cases in which a user has decided to publish on Facebook only. 


\section{DISCUSSION AND CONCLUSIONS}

This study is designed to reflect on the origins and transformation of so-called 'Action Art' in Artivism due to the use of social networks that present a delocalized panorama of political art engaged in the present. The study investigates the circulation of the term on Twitter and Instagram, networks that mainly use images, and conducts a quantitative study of the hashtags directly related to Artivism. It offers an interpretation of how the virtual maps that are generated with the dissemination of this type of manifestations are detached from their national territories, and it questions whether they really transcend borders or if the geopolitical differences that are reconstituted in the networks are also reconstructed.

In the first place, the central hypothesis has been validated: in its origins, Action Art was linked to the space-time in which the artistic manifestation took place, but its contents and possibilities have been transformed and evolved to what is today called Artivism, where each receiver can instantly become an information-transmitting agent. The artist, his work and his audience are no longer tied to a place and a moment. The artistic action is no longer reproduced once. Now, it is shared throughout the world and fans can keep it on their devices.

After the literature review, it is detected that the beginnings of Action Art are not clear, due to its open nature. Therefore, it is more interesting to reflect using the theoretical categories of 'postmodern art', as part of a social and historical framework, without individual geniuses, rather than basing it on the formal or creative characteristics of the works. This idea is linked to the second part of the study, which has collected the hashtags published related to Artivism and Action Art. Based on Keyhole software data, influencers have been detected with their publications, their visualizations and mentions, the countries of origin and the most used electronic devices. The results show the virality and internationalization of Artivism and Action Art. Some hashtags of low initial relevance became viral, reaching the five continents, with very few primary publications. The \#actionart, \#artivism and \#performance hashtags prove that social networks have helped Action Art overcome spatial-temporal barriers. Starting from a few dozen publications, the photographs and videos of artists almost reached 100,000 users, or even more in some cases.

Future studies can delve into the last two areas: country of origin and electronic device used. The countries of origin have shown very positive data: Artivism is present on all continents and in very different countries. Cultural and economic differences especially are striking. Future research could focus on analysing and discussing whether the cultural gap can be eliminated and whether artists can educate and make people literate in art, thanks to social networks. On the other hand, the chosen electronic devices show the immediate future of where technologies, devices or applications should go, to be more attractive to artists and followers of those artists.

Action Art has become Artivism thanks to social networks. It is present on Instagram and can reach audiences in every country, of all ages and in any geographical, rural or urban area. This type of creative action has united art and everyday life, bringing people closer together, without commercial barriers. It has no nationality, times, or maps. It remains an alternative, friendly, human culture. The self-managed artist manages his work and the selfenthusiast manages his admiration. The hashtags summarize and combine wills to create a new political, social and, of course, artistic debate. They are an interesting call to gather feelings, demands and emotions. Future research 
will study if hashtags could be a new quantifiable bastion of the success and engagement of artists and ideas.

\section{ACKNOWLEDGEMENTS}

Banco Santander-Universidad Complutense de Madrid Project. Title: 'Digital gap between teachers and university students: Cultural production and consumption through social networks (Facebook, Instagram and Twitter)'. Duration: 23 November 2017-30 June 2019. Reference: PR41/17-20959.

R\&D Project, Excellence Program, State sub-program of knowledge generation. Ministry of Economy, Industry and Competitiveness. Reference: FEM2017-83302-C3-3-P. Cultural Produsage in social networks: industry, popular consumption and audio-visual literacy of Spanish youth with a gender perspective (2018-22).

\section{REFERENCES}

Aladro-Vico, E., Jivkova-Semova, D. and Bailey, O. (2018), 'Artivism: A new educative language for transformative social action', Comunicar, 26:57, pp. 9-18, https://doi.org/10.3916/C57-2018-01. Accessed 15 April 2019.

Alvídrez, S. and Franco, O. (2016), 'Powerful communication style on Twitter: Effects on credibility and civic participation', Comunicar, 47:24, pp. 89-97, https://doi.org/10.3916/C47-2016-09. Accessed 15 April 2019.

Andújar-Vaca, A. and Cruz-Martínez, M. (2017), 'Mobile instant messaging: WhatsApp and its potential to develop oral skills', Comunicar, 50:25, pp. 43-52, https://doi.org/10.3916/C50-2017-04. Accessed 15 April 2019.

Bishop, K. and Corkery, L. (eds) (2017), Designing Cities with Children and Young People, London: Routledge.

Borges-Rey, E. (2015), 'News images on Instagram', Digital Journalism, 3:4, pp. 571-93, https://doi.org/10.1080/21670811.2015.1034526. Accessed 15 April 2019.

Bratich, J. (2014), 'Occupy all the dispositifs: Memes, media ecologies, and emergent bodies polic', Communication and Critial/Cultural Studies, 11:1, pp. 64-74.

Caldeira, S. P. and Ridder, S. de (2017), 'Representing diverse femininities on Instagram: A case study of the body-positive @effyourbeautystandards Instagram account', Catalan Journal of Communication \& Cultural Studies, 9:2, pp. 321-37, https://doi.org/10.1386/cjcs.9.2.321_1. Accessed 15 April 2019.

Camilli-Trujillo, C. and Römer-Pieretti, M. (2017), 'Meta-synthesis of literacy for the empowerment of vulnerable groups', Comunicar, 53:25, pp. 9-18, https://doi.org/10.3916/C53-2017-01. Accessed 15 July 2018.

Castihlo, R. and Romancini, F. (2017), 'How to occupy a school? I search the Internet!: Participatory politics in public school occupations in Brazil', Intercom: Revista Brasileira de Ciências da Comunicação, 40:2, pp. 93-109, http://dx.doi.org/10.1590/1809-5844201726. Accessed 15 April 2019.

Chen, H. (2017), 'College-aged young consumers' perceptions of social media marketing: The story of Instagram', Journal of Current Issues y Research in Advertising, 39:1, pp. 22-36, https://doi.org/10.1080/10641734.2017.137232 1. Accessed 15 April 2019.

Choi, G. Y. and Lewallen, J. (2017), 'Say Instagram, kids!: Examining sharenting and children's digital representations on Instagram', Howard Journal of Communications, 29:2, pp. 1-21, https://doi.org/10.1080/10646175.2017.132 7380. Accessed 15 April 2019. 
Cmeciu, C. and Coman, C. (2016), 'Digital civic activism in Romania: Framing anti-Chevron online protest community "faces"', Comunicar, 47:24, pp. 19-28. https://doi.org/10.3916/C47-2016-02. Accessed 15 April 2019.

Cummings, C. (2016),'Instagram', Adweek, 23 May, 38, p. 32.

Dalziell, T. and Kim, L. V. (2015), 'Self-regarding: Looking at photos in life writing', Life Writing, 12:4, pp. 377-81, https://doi.org/10.1080/14484528.20 15.1084580. Accessed 15 April 2019.

Dias-Fonseca, T. and Potter, J. (2016), 'Media education as a strategy for online civic participation in Portuguese schools', Comunicar, 49:24, pp. 9-18, https://doi.org/10.3916/C49-2016-01. Accessed 15 April 2019.

Díez-Gutiérrez, E. and Díaz-Nafría, J. (2018), 'Ubiquitous learning ecologies for a critical cybercitizenship', Comunicar, 54:26, pp. 49-58, https://doi. org/10.3916/C54-2018-05. Accessed 15 April 2019.

Goldberg, R. (2011), Performance Art: From Futurism to the Present, London: Thames \& Hudson World of Art.

Goris, Y. and Hollander, S. (2017), 'Activism, artivism and beyond: Inspiring initiatives of civic power', TheSpindle.org, 26 June, https://thespindle.org/ wp-content/uploads/2017/06/Activism-Artivism-and-Beyond-PDF-2017. pdf. Accessed 15 April 2019.

Herrero-Diaz, P. and Ramos-Serrano, M. (2018), ‘Breaking stereotypes online: Young activists' use of the Internet for social well-being', Catalan Journal of Communication \& Cultural Studies, 10:1, pp. 99-114, https://doi.org/10.1386/ cjcs.10.1.99_1. Accessed 15 April 2019.

Howell, A. (1999), The Analysis of Performance Art: A Guide to its Theory and Practice, London: Routledge.

Huntington, H. E. (2016), 'Pepper Spray Cop and the American Dream: Using synecdoche and metaphor to unlock Internet memes' visual political rhetoric', Communication Studies, 67:1, pp. 77-93.

Jacobs, J. (1961), The Death and Life of Great American Cities, New York: Random House.

Jameson, F. (1992), Postmodernism or, the Cultural, Logic of Late Capitalism, Durham: Duke University Press.

Jivkova, D., Requeijo, P. and Padilla, G. (2017), 'Uses and tendencies of Twitter in the campaign to the Spanish general elections of 2015 20D: Hashtags that were trending topic', El Profesional de la Información, 26:5, pp. 824-37, https://doi.org/10.3145/epi.2017.sep.05. Accessed 15 April 2019.

Korpijaakko, M. L. (2015), Cracking Facebook: The Importance of Understanding Technology-Based Communication, Rotterdam: SensePublishers.

Lane, D. S. and Dal Cin, S. (2017), 'Sharing beyond Slacktivism: The effect of socially observable prosocial media sharing on subsequent offline helping behavior', Information, Communication y Society, 21:11, pp. 1-18, https://doi. org/10.1080/1369118X.2017.1340496. Accessed 15 April 2019.

Lim, M. (2012), 'Clicks, cabs, and coffee houses: Social media and oppositional movements in Egypt, 2004-2011', Journal of Communication, 62:2, pp. 231-48, https://doi.org/10.1111/j.1460-2466.2012.01628.x. Accessed 15 April 2019.

Lis, P. F. de (2017), 'Instagram tiene 12 millones de usuarios en España', Elpais.com, 20 May, https://elpais.com/tecnologia/2017/05/30/actualidad/1496130523_675595.html. Accessed 15 April 2019.

Manovich, L. (2016), Instagram and Contemporary Image, New York: Cultural Analytics Lab. 
Míguez-González, M. I. and Huertas, A. (2015), 'The power of photographs in the communication and public relations of tourist destinations and their brands through Facebook and Flickr', Catalan Journal of Communication $\mathcal{E}$ Cultural Studies, 7:2, pp. 197-215, https://doi.org/10.1386/cjcs.7.2.197_1. Accessed 15 April 2019.

Milner, R. M. (2013), 'Pop polyvocality: Internet memes, public participation, and the Occupy Wall Street Movement', International Journal of Communication, 7, pp. 2357-90.

Pérez, K. and Corey, F. C. (2015), 'Introduction: The edges of performance', Text and Performance Quarterly, 35:4, pp. 263-65.

Poch, A. and Poch, D. P. (2018a), Artivism, London: Carpet Bombing Culture. (2018b), Creative Expressions in Contemporary Cities, London: Pro-Active Comunicationes.

Postill, J. (2014), 'Freedom technologists and the new protest movements: A theory of protest formulas', Convergence: The Journal of Research into New Media Technologies, 20:4, pp. 402-18.

Poulsen, S. V. (2018), 'Becoming a semiotic technology - a historical study of Instagram's tools for making and sharing photos and videos', Internet Histories, 2:1\&2, pp. 121-39, https://doi.org/10.1080/24701475.2018.14593 50. Accessed 15 April 2019.

Riley, S. C. E. and Cahill, S. (2005), 'Managing meaning and belonging: Young women's negotiation of authenticity in body art', Journal of Youth Studies, 8:3, pp. 261-79.

Russmann, U. and Svensson, J. (2016), 'Studying organizations on Instagram', Information, 7:4, pp. 58-70, https://doi.org/10.3390/info7040058. Accessed 15 April 2019.

Saura, G., Muñoz-Moreno, J., Luengo-Navas, J. and Martos-Ortega, J. (2017), 'Protesting on Twitter: Citizenship and empowerment from public education', Comunicar, 53:25, pp. 39-48, https://doi.org/10.3916/C53-2017-04. Accessed 15 April 2019.

Senabre, E., Ferrán-Ferrer, N. and Perelló, J. (2018), 'Participatory design of citizen science experiments', Comunicar, 54:26, pp. 29-38, https://doi. org/10.3916/C54-2018-03. Accessed 15 April 2019.

Sendra, A. and Farré, J. (2017), 'Institutional pain communication via Twitter by Spanish and US pain societies: Analysis of levels of use and engagement', Catalan Journal of Communication \& Cultural Studies, 9:1, pp. 3-23, https:// doi.org/10.1386/cjcs.9.1.3_1. Accessed 15 April 2019.

Simoens, J. A. and Campos, R. (2016), 'Youth, social movements and protest digital networks in a time of crisis', Comun: Mídia Consumo, 13:38, pp. 126-45. Accessed 15 April 2019.

Smith, S. P. (2018), 'Instagram abroad: Performance, consumption and colonial narrative in tourism', Postcolonial Studies, 21:1, pp. 1-20, https://doi.org/10. 1080/13688790.2018.1461173. Accessed 15 April 2019.

The Social Media Family (2018), 'IV Informe del uso de las redes sociales en España', The Social Media Family, 20 February, https://thesocialmediafamily.com/informe-redes-sociales/. Accessed 15 April 2019.

Torrego, A. and Gutiérrez-Martín, A. (2016), 'Watching and tweeting: Youngsters' responses to media representations of resistance', Comunicar, 47:24, pp. 9-17, https://doi.org/10.3916/C47-2016-01. Accessed 15 April 2019.

Treré, E. and Mattoni, A. (2016), 'Media ecologies and protest movements: Main perspectives and key lessons', Information, Communcation \& Society, 19:3, pp. 290-306. 
Tufekci, Z. and Wilson, C. (2012), 'Social media and the decision to participate in political protest: Observations from Tahrir Square', Journal of Communication, 62:2, pp. 363-79, https://doi.org/10.1111/j.1460-2466. 2012.01629.x. Accessed 15 April 2019.

Tuzel, S. and Hobbs, R. (2017), 'The use of social media and popular culture to advance cross-cultural understanding', Comunicar, 51:25, pp. 63-72, https://doi.org/10.3916/C51-2017-06. Accessed 15 April 2019.

Visa, M., Serés, T. and Soto, J. (2018), 'From the family portrait to the profile picture: Uses of photography in the Facebook social network', Revista Latina de Comunicación Social, 73, pp. 718-29, http://www.revistalatinacs. org/073paper/1278/37en.html. Accessed 15 April 2019.

Weibel, P. (2015), Global Activism: Art and Conflict in the 21st Century, Karlsruhe: ZKM Center for Art and Media.

Zhang, W. (2013), 'Redefining youth activism through digital technology in Singapore', International Communication Gazette, 75:3, pp. 253-70, https:// doi.org/10.1177/1748048512472858. Accessed 15 April 2019.

\section{SUGGESTED CITATION}

Bernárdez-Rodal, A., Padilla-Castillo, G. and Sosa-Sánchez, R. P. (2019), ‘From Action Art to Artivism on Instagram: Relocation and instantaneity for a new geography of protest', Catalan Journal of Communication \& Cultural Studies, 11:1, pp. 23-37, doi: 10.1386/cjcs.11.1.23_1

\section{CONTRIBUTOR DETAILS}

Asunción Bernárdez Rodal is full professor and director of the Feminist Research Institute of the Complutense University of Madrid (UCM). She is a professor of gender and communication, the semiotics of mass media and information and information theory. She is current leader of the R\&D excellence project titled 'Cultural produsage in social networks: Industry, popular consumption and audio-visual literacy of Spanish youth with gender perspective'; and the Santander Bank-UCM project titled 'Digital divide between university teachers and students: Production and cultural consumption through social networks (Facebook, Twitter and Instagram)'. She is the author of numerous international high-impact research works related to the analysis of gender discourses, both textual and audio-visual.

Contact: School of Information Sciences, Complutense University of Madrid, Avenida Complutense s/n, 28040, Madrid, Spain.

E-mail: asbernar@ucm.es

Web address: https://scholar.google.com/citations?user=TOKIVQEAAAAJ\&hl=es

ํ. http://orcid.org/0000-0003-4081-0035

Graciela Padilla Castillo is the coordinator of the BA programme in Journalism of the School of Information Sciences of the Complutense University of Madrid (UCM). She is the Member of the Feminist Research Institute (UCM). Her research interests focus on information theory, ethics and deontology of communication, TV fiction and gender studies. She is author and co-author of 100 book chapters and scholarly articles published in high-impact journals. Has coordinated more than ten collective works and has participated in more than 30 competitive and private research and teaching-innovation projects. 
Contact: School of Information Sciences, Complutense University of Madrid, Avenida Complutense s/n, 28040, Madrid, Spain.

E-mail: gracielp@ucm.es

Web address: https://scholar.google.es/citations?user=zeT1SLkAAAAJ\&hl=es

슨 https://orcid.org/0000-0003-1393-4817

Roxana Popelka Sosa Sánchez is a university professor and writer. She directed the literary magazine Lunula of the Ateneo Obrero de Gijón. Currently collaborates in the magazines Madriz, Diagonal and Culturamas of Madrid. Since 1996, she has been devoted, in parallel, to the art of action, performing numerous performances inside and outside of Spain. She is co-director and scriptwriter of several short films: La vida en un corto (2003) or El aparcamiento (2005), which was the winner in the 2005 edition of the Gijón Film Festival (day of Asturias), and selected in the independent film festival in Canada.

Contact: School of Information Sciences, Complutense University of Madrid, Avenida Complutense s/n, 28040, Madrid, Spain.

E-mail: rpsosa@ccinf.ucm.es

스 http://orcid.org/0001-5922-826X

Asunción Bernárdez Rodal, Graciela Padilla Castillo and Roxana Popelka Sosa Sánchez have asserted their right under the Copyright, Designs and Patents Act, 1988, to be identified as the authors of this work in the format that was submitted to Intellect Ltd. 


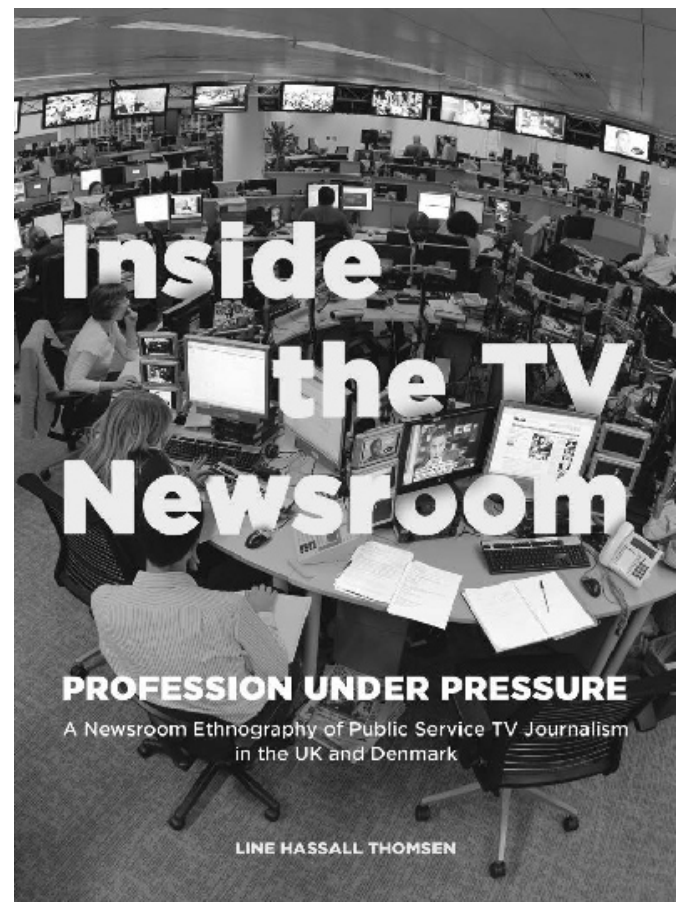

\section{Inside the TV Newsroom}

Profession under Pressure. A Newsroom Ethnography of Public Service TV Journalism in the UK and Denmark By Line Hassall Thomsen

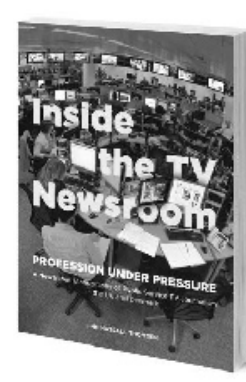

ISBN 978-1-78320-883-8 322 pp | £37, \$49 Paperback | Spring 2018 $230 \times 170 \mathrm{~mm}$ eBook available
In an era where the way people get news is ever-changing, how do broadcast journalists work? How do changes to the field affect journalists at traditional public broadcasters? And what similarities are there between licence-funded news programs - like those on the $\mathrm{BBC}$ - and commercial news?

This book, built on years of unique access to the newsrooms of BBC News and ITV News in the United Kingdom, and DR TV Avisen and TV2 Nyhedeme in Denmark, answers those questions and more. Exploring the shared professional ideals of journalists, the study analyses how they conceive of stories as important, and how their ideals relating to their work are expressed and aspired to in everyday practice. 
Copyright of Catalan Journal of Communication \& Cultural Studies is the property of Intellect Ltd. and its content may not be copied or emailed to multiple sites or posted to a listserv without the copyright holder's express written permission. However, users may print, download, or email articles for individual use. 